\title{
Protective Effect of Amifostine against Etoposide-Induced Genotoxicity Evaluated By the Comet Assays
}

\author{
Mohammad Shokrzadeh and Nasrin Ghassemi-Barghi* \\ Department of Pharmacology and Toxicology, Faculty of Pharmacy, Student Research Committee, Mazandaran \\ University of Medical Sciences, Sari, Iran
}

Received: May 21, 2018; Accepted: June 21, 2018; Published: June 25, 2018

*Corresponding author: Nasrin Ghassemi-Barghi, Department of Pharmacology and Toxicology, Faculty of Pharmacy, Student Research Committee, Mazandaran University of Medical Sciences, Sari, Iran, Tel: 00989146191720; E-mail: Ngeternal67@yahoo.com

\begin{abstract}
Etoposide is one of the most effective chemotherapeutic agents used for the treatment of number of neoplasia. However, as a topoisomerase inhibitor, during clinical use several side effects may occur. In addition in several in vivo and in vitro studies etoposide has shown a range of genotoxic effects including mutation induction and inhibition of DNA synthesis. Amifostine, an organic thiophosphate prodrug, has been shown to exert important cyto-protective effects in many tissues. The aim of this study was to explore whether amifostine protects against etoposide-induced genotoxicity in HepG2 cell line. HepG2 cells $\left(25 \times 10^{4}\right.$ cells/well $)$ were cultured in 24 -well plates: a control group and three 'amifostine etoposide groups (pre and co- treatment conditions). Our results show that etoposide induced a noticeable genotoxic effect in HepG2 cells. Amifostine reduced the effects of etoposide significantly in both type of experiment conditions, through reduced the level of DNA damage measured via comet andmicronucleus assay. Furthermore, amifostine decreased the intracellular ROS generation induced by etoposide. It increased also the intracellular GSH levels in HepG2 cells. Altogether, our results suggest a protective action of amifostine against etoposide cytotoxicity and genotoxicity via various pathways. The most protective effect was observed with amifostine when it was administrated $24 \mathrm{~h}$ before etoposide treatment.
\end{abstract}

Keywords: Etoposide; Amifostine; Comet; Micronucleus; ROS; GSH

\section{Introduction}

Etoposide is an anticancer drug used alone or in combination with other drugs in chemotherapy of testicular cancer, lung cancer, lymphoma, leukemia, neuroblastoma and ovarian cancer [1-5]. Side effects of treatment include, vomiting, neutropenia, myelosuppression and alopecia [6-8]. Former studies reported an acute myeloid leukemia as a secondary cancer subsequent treatment by etoposide. Also, etoposide is involved in secondary malignancies because of its genotoxic potential in normal tissues[9, 10].

Topoisomerases are enzymes that catalyze the transient breakage and rejoining of either one or two DNA strands, to allow one strand to cross another and prevent indeterminable masses during processes such as DNA replication[11, 12]. As a potent topoisomerase inhibitor, etoposide can cause DNA damage by generating a "lesion" that includes DNA strand breaks and protein covalently bound to DNA.[13].Several in vitro and in vivo reports have shown that etoposide induce apoptosis and senescence in different cell lines. Moreover, treatment with etoposide can result in intracellular glutathione (GSH) depletion and increase reactive oxygen species (ROS) generation [1416]. Etoposide has shown diverse genotoxic effects including mutation induction and several complaints in DNA synthesis in numerous animal and cell line studies $[10,17]$. The genotoxicity of etoposide have been evidenced in chromosome aberration tests, micronucleus assays and comet assay in various studies $[10,18,19]$. Second malignancies detected in patients earlier treated with topoisomerase II interactive agents propose these may be a significant clinical outcome of their ability to induce mutation[20].

Amifostine (AMF, WR-2721), is a cytoprotective adjuvant used in cancer chemotherapy and radiotherapy involving DNAbinding chemotherapeutic agents [21]. Amifostine is an organic thiophosphate prodrug which is hydrolyzed in vivo by alkaline phosphatase to the active cytoprotective thiols metabolite, WR-1065[22, 23]. According to the several reports, inside the cell, amifostine's protective effects appear to be mediated by scavenging free radicals, hydrogen donation, induction of cellular hypoxia, the release of endogenous nonprotein sulfhydryl's (mainly glutathione) from their bond with cell proteins, the formation of mixed disulphides to protect normal cells [24].

Amifostine has shown remarkable radio and chemo protective effects in vitro and in vivo. It is currently approved for clinical use as a protective agent against renal toxicity induced by cisplatin in patients being treated for ovarian cancer and against xerostomia induced by ionizing radiation in patients with head and neck cancer [25-28].

Single cell gel electrophoresis (comet assay) is widely used in genotoxicity testing and is also becoming an important and sensitive tool for evaluating genotoxic potential of compounds such as mutagens and/or antimutagenic agents and carcinogens in vivo and in vitro. In the comet assay, induced DNA damage is evaluated after single cell gel electrophoresis by measuring the tail moment as the product of percent tail DNA multiplied by the tail length of the comet and the percent head DNA. After alkaline lysis, damaged DNA originating from DNA strand breaks and 
alkali-labile sites thereby pass out of the nuclei moving towards the anode along the electrical field and form comet-like structures [29].

The aim of present study was to investigate the protective effect of amifostine against etoposide induced genotoxicity. For this purpose we measure the DNA damage level with comet assay in HepG2 cells treated with etoposide and amifostine in pretreatment experimental conditions. We also measured intracellular ROS generation and GSH levels in cells treated with etoposide and amifostine in pre-treatment condition.

\section{Material and Method}

\section{Chemicals}

Etoposide was purchased from sigma-Aldrich, France. Amifostine, EDTA, H2O2, NaCl, NaOH, Na2CO3, NaH2PO4, Tris, and Triton X-100 were acquired from Merck Co. (Germany). Low melting point agarose (LMA), Na2HPO4, $\mathrm{KCl}$ and ethidium bromide were from Sigma Co. (USA). Normal melting point agarose (NMA) was supplied by Cinnagen Co (Germany). The RPMI 1640 medium, fetal bovine serum (FBS) and the antibiotic were purchased from biosera (France). DCFH-DA probe and $\mathrm{mBCl}$ were from sigma Aldrich (USA) And, HepG2 cells came from Pasture Institute (Iran). All other chemicals used were of analytical grade.

\section{Cell culture}

Human hepatoma (HepG2) cells were obtained from Pasture Institute of Iran were grown as monolayer culture in RPMI 1640 medium supplemented with $10 \%$ FBS, $1 \%$ of mixture of penicillin $(100 \mathrm{IU} / \mathrm{ml})$ and streptomycin $(100 \mu \mathrm{g} / \mathrm{ml})$ incubated at $37^{\circ} \mathrm{C}$ in an atmosphere of 5\% CO2-95\% air mixture. Amifostine was dissolved in the cell culture medium. We have chosen untreated cells as a control. Cells were seeded in 24-well culture plates at $25 \times 10^{4}$ cells/well, after overnight growth, cells treated with studied concentrations of amifostine (1,5 and $10 \mathrm{mg} / \mathrm{ml}) 24 \mathrm{~h}$ prior and Simultaneously to etoposide treatment $(1 \mu \mathrm{M})$ for $1 \mathrm{~h}$ at $37^{\circ} \mathrm{C}$ [29].

\section{Single-cell gel electrophoresis (SCGE, the comet assay)}

The comet assay procedure has been described in our previous studies (29-32). Briefly, incubated cell suspensions (1 $\times 10^{6}$ cells $/ \mathrm{ml}$ ) were mixed with $1 \%$ LMP agarose at $37 \stackrel{\circ}{\circ}$, were placed on the precoated slides (1\% NMP agarose), and covered by cover glasses for $5 \mathrm{~min}$ at $2-8{ }^{\circ} \mathrm{C}$. The slides were incubated with lysis solution ( $\mathrm{pH}=10.0)$ for $40 \mathrm{~min}$ and rinsed with distilled water to remove the excess lysis solution. In the next step, slides were incubated with electrophoresis buffer $(\mathrm{pH}>13.0)$ for 40 min. Electrophoresis was conducted for $40 \mathrm{~min}$ at $25 \mathrm{~V}$ with an electricity current adjusted to $300 \mathrm{~mA}$. After this stage, the slides were rinsed with distilled water to remove excess alkaline buffer and were placed in the neutralization solution $(\mathrm{pH}=7.5)$ for 10 min. The slides were covered by sufficient dye solution $(20 \mu \mathrm{g} /$ $\mathrm{ml}$ ethidium bromide) for $5 \mathrm{~min}$ and washed with distilled water. Finally comets were visualized under $\times 400$ magnification using fluorescence microscope with an excitation filter of 510-560 $\mathrm{nm}$ and the barrier filter of $590 \mathrm{~nm}$ (23). All stages of comet assay were performed in dark conditions and all solutions were prepared freshly and used cool [30].

\section{Measurement of Oxidative Stress}

Approximately $4 \times 10^{4}$ cells per well were cultured for 24 $\mathrm{h}$ in 96-well plates (black-wall/clear-bottom). Thereafter, the medium was aspirated, and the cells were washed twice with HBSS. The cells were then treated with studied concentrations of amifostine (1, 5 and $10 \mathrm{mg} / \mathrm{ml}) 24 \mathrm{~h}$ prior etoposide treatment $(1 \mu \mathrm{M})$ for $1 \mathrm{~h}$ at $37^{\circ} \mathrm{C}$. After the treatment, cells were washed twice with HBSS and incubated in $2 \mathrm{ml}$ of fresh culture medium without FBS. 2, 7_ Dichlorodihydrofluorescein diacetate was added at a final concentration of $10 \mu \mathrm{M}$ and incubated for $20 \mathrm{~min}$. The cells were then washed twice with PBS and maintained in 1 $\mathrm{ml}$ of culture medium. Assess ROS by immediately analyzing cells by fluorescence plate reader using the $488 \mathrm{~nm}$ for excitation and detected at $535 \mathrm{~nm}$. we have chosen untreated cells as a negative control and cells treated with $0.1 \mathrm{mM} \mathrm{H} 2 \mathrm{O} 2$ as a positive control $[29,31]$

\section{Measurement of intracellular GSH levels}

HepG2 cells were plated in a 96-well plate at 50,000 cells/ well. After overnight growth, they were treated with test vehicles and then incubated with monochlorobimane (mBCI, $40 \mu \mathrm{M})$ in a staining solution (5mMglucose, $1 \mathrm{mM} \mathrm{CaCl} 2,0.5 \mathrm{mMMgSO} 4,5$ $\mathrm{mg} / \mathrm{ml} \mathrm{BSA}$ ) for $30 \mathrm{~min}$ at $37^{\circ} \mathrm{C}$ in the dark. Although $\mathrm{mBCI}$ is a nonfluorescent probe, it forms a stable fluorescent adduct with GSH in a reaction catalyzed by the GSH S-transferases. The mean fluorescent intensity of the fluorescent GSH-bimane adduct was measured using a Spectra fluorescent plate reader at $\lambda \mathrm{ex}=380$ $\mathrm{nm}$ and $\lambda \mathrm{em}=460 \mathrm{~nm}$ to detect GSH. The assay was performed for amifostine for studied concentration $(1,5$ and $10 \mathrm{mg} / \mathrm{ml})$ and etoposide $(1 \mu \mathrm{M})$ in pretreatment condition, [29]

\section{Statistical analysis}

Tail moment (percentage of DNA in the tail $\times$ tail length), tail length (the length of the comet tail), and percent of DNA in the tail (percentage of colored spots in tail) are the most frequently used factors in the evaluation of DNA damages in the comet assay method. We used these factors for statistical analysis in this investigation. One-way analysis of variance (ANOVA) followed by Tukey's multiple comparison post hoc tests was used to compare the results of all assays. Value of $p<0.05$ was considered to be significant.

\section{Results}

\section{Study the effect of amifostine on etoposide-induced DNA damage}

The anti-genotoxic effect of amifostine was investigated through the alkaline comet assay. Results of the visual scoring and percentage of total DNA damage induced by etoposide and prevented by amifostine were shown in Table 1.We observed that etoposide treatment at $1 \mu \mathrm{M}$ induced a significant $(\mathrm{p}<0.001)$ increase in DNA damage as compared to the control group. Amifostine in the different treatment conditions decreased 
Table 1: The genoprotective effect of Amifostine compared with control groups on tail length (pixels), percentage of DNA in tail, and tail moment (pixels) that are represented as mean \pm SEM. The sign $\left({ }^{*}\right)$ show significantly $(\mathrm{p}<0.0001)$ decreased compared to the etoposide group. (One-way ANOVA followed by tukeys post hoc test)

\begin{tabular}{|c|c|c|c|c|c|}
\hline \multirow{5}{*}{ Pre-treatment } & Treatment & $\begin{array}{l}\text { Tail length (Pixels) } \\
\text { (Mean } \pm \text { SEM) }\end{array}$ & $\begin{array}{c}\% \text { DNA in Tail } \\
\text { (Mean } \pm \text { SEM) }\end{array}$ & & $\begin{array}{l}\text { Tail moment } \\
(\text { Mean } \pm \text { SEM) }\end{array}$ \\
\hline & Control (Etoposide1 $\mu \mathrm{M}$ ) & $134.1 \pm 1.1$ & $69.5 \pm 1.9$ & \multirow{4}{*}{$41.3 \pm 0.8$} & $54.2 \pm 1.75$ \\
\hline & Amifostine $(1 \mathrm{mg} / \mathrm{ml})$ & $79.11 \pm 1.859 .25 \pm 1.7$ & & & \\
\hline & Amifostine $(5 \mathrm{mg} / \mathrm{ml})$ & $32.12 \pm 0.9 *$ & $14.2 \pm 0.3^{*}$ & & $8.1 \pm 0.7^{*}$ \\
\hline & Amifostine $(10 \mathrm{mg} / \mathrm{ml})$ & $18.2 \pm 1.18^{*} \#$ & $9.9 \pm 0.1^{*}$ & & $1.19 \pm .07 *$ \\
\hline
\end{tabular}

significantly $(\mathrm{p}<0.0001)$ the level of DNA fragmentation as compared to the etoposide group.

\section{Study the effect of amifostine on ROS generation in etoposide-treated cells}

To investigate the role of oxidative stress in etoposideinduced genotoxicity, we used DCFH-DA, a cell-permeable fluorescent dye, to examine the ROS generation in HepG2 cells in response to etoposide stimulation. Incubation with etoposide for $1 \mathrm{~h}$ showed a considerable increase in oxidant-induced $2_{-}$, 7_-dichlorofluorescein fluorescence in HepG2 cells (Figure 1). H2O2-mediated DCF fluorescence occurred after $1 \mathrm{~h}$ incubation with etoposide $(1 \mu \mathrm{M})$ in HepG2 cells. This suggests that etoposide, induce intracellular oxidative stress, involved in its genotoxicity. After that cells were treated with amifostine in pretreatment condition and subsequently examined. Amifostine was significantly $(\mathrm{p}<0.0001)$ reduced ROS generation as compared to the etoposide group. Untreated cells served as control.

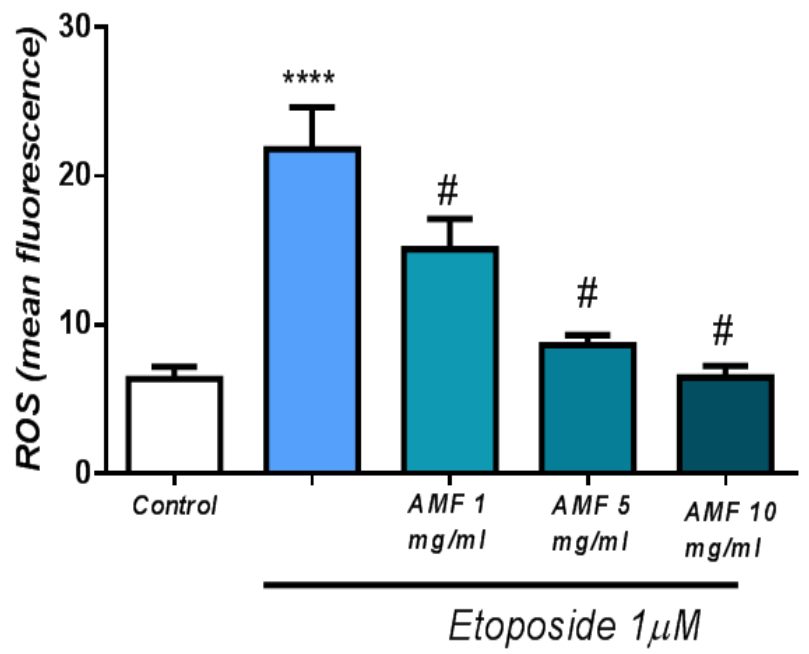

Figure 1: Study the effect of amifostine on etoposide-induced ROS generation. $\left({ }^{* * *}\right)$ show significantly increased results (respectively $\mathrm{p}<0.0001$ ) as compared to the control group. The sign (\#) show significantly $(\mathrm{p}<0.0001)$ decreased compared to the etoposide group

\section{Study the effect of etoposide on intracellular levels of} GSH

We first examined the effect of etoposide on the intracellular levels of GSH using mBCI which readily enters cells to form a fluorescent GSH-bimane adduct that can be measured fluorometrically. As shown in fig.2, within $1 \mathrm{~h}$ after etoposide $(1 \mu \mathrm{M})$ treatment, the intracellular levels of GSH were reduced $(\mathrm{p}<0.0001)$. This finding was subsequently confirmed by an enzymatic assay using glutathione reductase and 2-vinylpyridine. Next; we measured the intracellular levels of GSH in cells after treatment with amifostine and etoposide in pre- treatment condition. As shown in figure 2 amifostine were significantly $(p<0.0001)$ increased GSH levels as compared to the etoposide group.

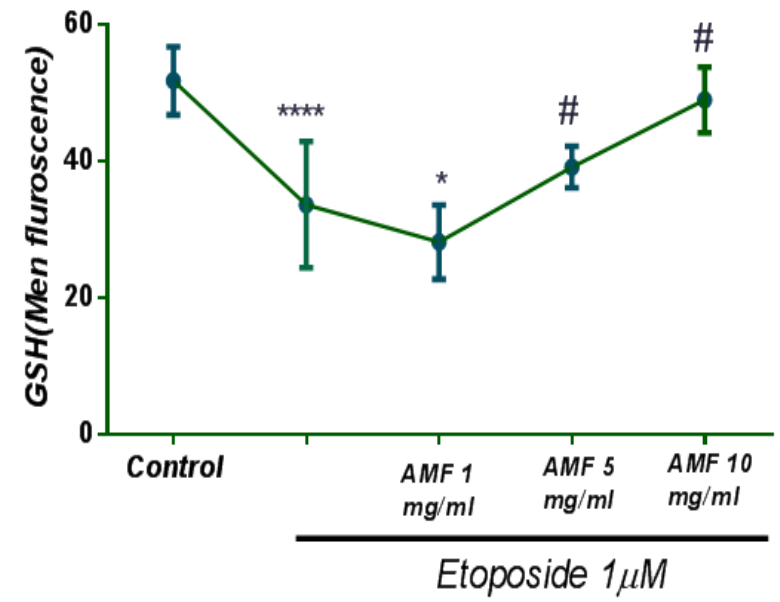

Figure 2: The effect of amifostine on the levels of intracellular GSH was determined .ANOVA analysis revealed that amifostine, significantly inhibited the effects of amifostine on the levels of GSH. Sign $\left({ }^{* * *}\right)$ and $\left({ }^{*}\right)$ show significantly decreased results (respectively $\mathrm{p}<0.0001$ and $\mathrm{p}<0.05$ ) as compared to the control group. Sign \# show significantly $(\mathrm{p}<0.0001)$ increased as compared to the amifostine group

\section{Discussion}

Etoposide as a chemotherapeutic agent is used in combination with other anticancer drugs in the treatment of many cancerous diseases such as testicular, bladder, prostate, lung, and uterine cancers [32, 33]. It seems that etoposide act as a topoisomerase II inhibitor, although the clear mechanism of action of this drug is not known[34]. Also, etoposide can induce secondary malignancies due to its genotoxic potential in normal tissues. As a strong topoisomerase II inhibitor agent etoposide can cause DNA damage by different mechanisms. The main mechanism of 
action proposed for topoisomerase II inhibitor as etoposide is steady the double-stranded DNA cleavage normally catalyzed by topoisomerase II (topo II) and inhibit accurate relegation of DNA breaks. These double-strand DNA breaks not only consequently prompt the anticipated antitumor effects of the drugs but also interact with normal cells and induce genotoxicity $[35,36]$.

Amifostine, is the most effective radioprotector known and the only one accepted for clinical use in cancer radiotherapy [37]. This antigenotoxic effect was explained by assuming a high affinity of amifostine for DNA, thereby stabilizing the DNA molecule and facilitating the activity of DNA repair enzymes [38]. Previous studies using mammal cells have shown that amifostine enhances DNA repair and thus improves cell survival. Amifostine phosphorylated aminothiol, also is an antioxidant clinically prescribed to prevent the neutropenia-associated events in patients receiving alkylating agents [39]. In experimental animals, Yuhas and Storer showed that treatment with AMF effectively protects normal tissue from the toxicity of therapeutic radiation, without protecting tumor [40]. Nagy et al. subsequently showed that AMF showed the protective effect against the mutagenicity of cisplatin, evaluated by the mutation rate of HPRT in V79 Chinese hamster cells [41]. Other reports documented that amifostine protects normal tissue against radiation-induced damage by increasing intracellular SOD2 activity. Once dephosphorylated by the membrane-bound alkaline phosphatase (ALP), AMF is activated to a free thiol form (WR-1065), which is preferentially up taken by normal cells, since ALP is more active and efficiently expressed in normal rather than neoplastic tissue [42]. Moreover, in another study found that WR1065, the active free thiol form of amifostine, induces antioxidative ability against radiation via SOD2 in vitro[43].

In our investigation we quantified the DNA-damage level, to elucidate the possible anti-genotoxic mechanism of amifostine against etoposide-induced toxicity in HepG2 cell line. Our results showed that etoposide alone caused a significant increase in DNA fragmentation as compared to the untreated cells. However, treatment of HepG2 cells with amifostine $24 \mathrm{~h}$ before etoposide administration induced a noticeable decrease in DNA fragmentation as compared to the etoposide-treated group. Measurement of ROS generation showed that etoposide induced ROS generation. Amifostine is a potent cytoprotective agent that can inhibit oxidative stress by scavenging ROS and replenishing GSH.

\section{Conclusion}

In conclusion, we have demonstrated that amifostine protected Hepg2 cells against etoposide -induced DNA damage and oxidative injury. Furthermore, we showed that etoposide increased intracellular ROS generation and decreased intracellular GSH levels. Amifostine ameliorated the balance of intracellular antioxidants and oxidants, decreased ROS generation and enhanced the intracellular level of GSH. Altogether, our results suggest a protective action of amifostine against etoposide cytotoxicity and genotoxicity via various pathways. The most protective effect was observed with amifostine when it was administrated $24 \mathrm{~h}$ before etoposide treatment.

\section{References}

1. Mezvrishvili $\mathrm{Z}$ and L Managadze. Three cycles of etoposide and cisplatin chemotherapy in clinical stage IS nonseminomatous testicular cancer. Int Urol Nephrol. 2006;38(3-4):621-624.

2. Renata Rezonja, Lea Knez, Tanja Cufer and Ales Mrhar. Oral treatment with etoposide in small cell lung cancer-dilemmas and solutions. Radiol Oncol. 2013;47(1):1-13.

3. Stadtmauer EA, PA Cassileth and RP Gale. Etoposide in leukemia, lymphoma and bone marrow transplantation. Leukemia research. 1989;13(8):639-650.

4. Moosavi AS, Gilani MM, Tehranian A, Esfahani JK. Daily lowdose oral etoposide for recurrent epithelial ovarian cancer after platinum-based therapy. J Obstet Gynaecol. 2004;24(3):292-293.

5. Kim DW, Jo YH, Kim JH, Wu HG, Rhee CS, Lee CH, et al. Neoadjuvant etoposide, ifosfamide, and cisplatin for the treatment of olfactory neuroblastoma. Cancer. 2004;101(10):2257-2260.

6. Jordan K, Kasper C, Schmoll HJ. Chemotherapy-induced nausea and vomiting: current and new standards in the antiemetic prophylaxis and treatment. Eur J Cancer. 2005;41(2):199-205.

7. Hofland KF, Thougaard AV, Sehested M, Jensen PB. Dexrazoxane Protects against Myelosuppression from the DNA CleavageEnhancing Drugs Etoposide and Daunorubicin but not Doxorubicin. Clin Cancer Res. 2005;11(10):3915-3924.

8. Tsuruki T, Takahata K, Yoshikawa M. A soy-derived immunostimulating peptide inhibits etoposide-induced alopecia in neonatal rats. J Invest Dermatol. 2004;122(3):848-850.

9. Ezoe S. Secondary leukemia associated with the anti-cancer agent, etoposide, a topoisomerase II inhibitor. International journal of environmental research and public health. 2012;9(7):2444-2453. doi: 10.3390/ijerph9072444

10. Turner SD1, Wijnhoven SW, Tinwell H, Lashford LS, Rafferty JA, Ashby J, et al. Assays to predict the genotoxicity of the chromosomal mutagen etoposide-focussing on the best assay. Mutat Res. 2001;493(1-2):139-147.

11. Khodursky AB, Peter BJ, Schmid MB, DeRisi J, Botstein D, Brown PO, et al. Analysis of topoisomerase function in bacterial replication fork movement: use of DNA microarrays. Proc Natl Acad Sci U S A. 2000;97(17):9419-9424.

12.John L Nitiss. DNA topoisomerase II and its growing repertoire of biological functions. Nat Rev Cancer. 2009;9(5):327-337. doi: $10.1038 / \mathrm{nrc} 2608$

13.John L. Nitiss. Targeting DNA topoisomerase II in cancer chemotherapy. Nat Rev Cancer. 2009;9(5):338-350.

14.Pentti Mäntymaa, Timo Siitonen, Tanja Guttorm, Marjaana Säily, Vuokko Kinnula, Eeva-Riitta, et al. Induction of mitochondrial manganese superoxide dismutase confers resistance to apoptosis in acute myeloblastic leukaemia cells exposed to etoposide. British journal of haematology. 2000;108(3):574-581.

15. Nicholas S Brown and Roy Bicknell. Hypoxia and oxidative stress in breast cancer Oxidative stress-its effects on the growth, metastatic potential and response to therapy of breast cancer. Breast cancer research. 2001;3(5):323-327. doi: 10.1186/bcr315

16.Kagan VE, Kuzmenko AI, Tyurina YY, Shvedova AA, Matsura T, Yalowich JC. Pro-oxidant and antioxidant mechanisms of etoposide 
in HL-60 cells. Cancer Res. 2001;61(21):7777-7784.

17. Sortibrán AN1, Téllez MG, Rodríguez-Arnaiz R. Genotoxic profile of inhibitors of topoisomerases I (camptothecin) and II (etoposide) in a mitotic recombination and sex-chromosome loss somatic eye assay of Drosophila melanogaster. Mutat Res. 2006;604(1-2):83-90.

18. Bueno C, Catalina P, Melen GJ, Montes R, Sánchez L, Ligero G, et al. Etoposide induces MLL rearrangements and other chromosomal abnormalities in human embryonic stem cells. Carcinogenesis. 2009;30(9):1628-37. doi: 10.1093/carcin/bgp169

19. Poul JM, Huet S, Godard T, Sanders P. Lack of genotoxicity of potassium iodate in the alkaline comet assay and in the cytokinesisblock micronucleus test. Comparison to potassium bromate. Food Chem Toxicol. 2004;42(2):203-209.

20. Relling MV, Boyett JM, Blanco JG, Raimondi S, Behm FG, et al. Granulocyte colony-stimulating factor and the risk of secondary myeloid malignancy after etoposide treatment. Blood. 2003;101(10):3862-3867.

21. Kanat O, Evrensel T, Baran I, Coskun H, Zarifoglu M, Turan OF, et al. Protective effect of amifostine against toxicity of paclitaxel and carboplatin in non-small cell lung cancer. Med Oncol. 2003;20(3):237-245

22.Stankiewicz A and E Skrzydlewska. Protection against cyclophosphamide-induced renal oxidative stress by amifostine: the role of antioxidative mechanisms. Toxicol Mech Methods 2003;13(4):301-308. doi: 10.1080/713857191

23.González EP, A Fuchs and GS Sánchez. Amifostine (WR2721) confers DNA protection to in vivo cisplatin-treated murine peripheral blood leukocytes. Dose-Response. 2009;7(3):08-026.

24. Torres VM and VD Simic. Doxorubicin-Induced Oxidative Injury of Cardiomyocytes-Do We Have Right Strategies for Prevention? INTECH Open Access Publisher. 2012.

25.Arany I, Safirstein RL. Cisplatin nephrotoxicity. Semin Nephrol 2003;23(5):460-464

26. Hartmann JT, Knop S, Fels LM, van Vangerow A, Stolte H, Kanz L, et al. The use of reduced doses of amifostine to ameliorate nephrotoxicity of cisplatin/ifosfamide-based chemotherapy in patients with solid tumors. Anti-cancer drugs. 2000;11(1):1-6.

27. Antonadou D, Pepelassi M, Synodinou M, Puglisi M, Throuvalas N. Prophylactic use of amifostine to prevent radiochemotherapyinduced mucositis and xerostomia in head-and-neck cancer. Int J Radiat Oncol Biol Phys. 2002;52(3):739-747

28.Santini V and FJ Giles. The potential of amifostine: from cytoprotectant to therapeutic agent. Haematologica. 1999;84(11):1035-1042.

29. Ghassemi-Barghi N, Varshosaz J, Etebari M, Jafarian Dehkordi A. Role of recombinant human erythropoietin loading chitosantripolyphosphate nanoparticles in busulfan-induced genotoxicity: Analysis of DNA fragmentation via comet assay in cultured HepG2 cells. Toxicol In Vitro. 2016;36:46-52. doi: 10.1016/j.tiv.2016.07.001

30.Ghassemi-Barghi N, Etebari M, Jafarian-Dehkordi A. Protective effect of amifostine on busulfan induced DNA damage in human hepatoma cells. Toxicol Mech Methods. 2017;27(1):52-57. doi: $10.1080 / 15376516.2016 .1243601$
31.Shokrzadeh $\mathrm{M}$ and $\mathrm{N}$ Ghassemi-Barghi. Antioxidant and Genoprotective Effects of Amifostine against Irinotecan Toxicity in Human Hepatoma Cells. International Journal of Cancer Research \& Therapy. 2018;3(1):1-5.

32. Bonomi P, Kim K, Fairclough D, Cella D, Kugler J, Rowinsky E, et al. Comparison of survival and quality of life in advanced non-smallcell lung cancer patients treated with two dose levels of paclitaxel combined with cisplatin versus etoposide with cisplatin: Results of an Eastern Cooperative Oncology Group trial. J Clin Oncol. 2000;18(3):623-631.

33. Noda K, Nishiwaki Y, Kawahara M, Negoro S, Sugiura T, Yokoyama A, et al. Irinotecan plus cisplatin compared with etoposide plus cisplatin for extensive small-cell lung cancer. $\mathrm{N}$ Engl J Med. 2002;346(2):85-91.

34.Xiaoliang Zhuo, Naiyu Zheng, Carolyn A Felix and Ian A Blair. Kinetics and regulation of cytochrome P450-mediated etoposide metabolism. Drug Metabolism and Disposition, 2004;32(9):9931000.

35.van Maanen JM, Retèl J, de Vries J, Pinedo HM. Mechanism of action of antitumor drug etoposide: a review. J Natl Cancer Inst. 1988;80(19):1526-1533.

36. Pommier Y, Leo E, Zhang H, Marchand C. DNA topoisomerases and their poisoning by anticancer and antibacterial drugs. Chem Biol. 2010;17(5):421-433. doi: 10.1016/j.chembiol.2010.04.012

37. Rades D, Fehlauer F, Bajrovic A, Mahlmann B, Richter E, et al. Serious adverse effects of amifostine during radiotherapy in head and neck cancer patients. Radiother Oncol. 2004;70(3):261-264.

38. Majsterek I, Gloc E, Blasiak J, Reiter RJ. A comparison of the action of amifostine and melatonin on DNA-damaging effects and apoptosis induced by idarubicin in normal and cancer cells. J Pineal Res. 2005;38(4):254-263.

39. Lorusso D, Ferrandina G, Greggi S, Gadducci A, Pignata S, Tateo $S$, et al. Phase III multicenter randomized trial of amifostine as cytoprotectant in first-line chemotherapy in ovarian cancer patients. Ann Oncol. 2003;14(7):1086-1093.

40.Ben-Josef E, Sue Han, Martin Tobi, Barbara J Vargas, Beth Stamos, Laura Kelly, et al. Intrarectal application of amifostine for the prevention of radiation-induced rectal injury. Seminars in radiation oncology. 2002;12(1):81-85.

41. Camelo RM, Kehdy FS, Salas CE, Lopes MT. Amifostine protection against mitomycin-induced chromosomal breakage in fanconi anaemia lymphocytes. Molecules. 2008;13(8):1759-1772.

42.Dziegielewski J, Baulch JE, Goetz W, Coleman MC, Spitz DR, Murley JS, et al. WR-1065, the active metabolite of amifostine, mitigates radiation-induced delayed genomic instability. Free Radic Biol Med. 2008;45(12):1674-1681. doi: 10.1016/j.freeradbiomed.2008.09.004

43. Khodarev NN, Kataoka Y, Murley JS, Weichselbaum RR, Grdina DJ. Interaction of amifostine and ionizing radiation on transcriptional patterns of apoptotic genes expressed in human microvascular endothelial cells (HMEC). Int J Radiat Oncol Biol Phys. 2004;60(2):553-563. 